\title{
Simulated Strategies to Customer Preferences in Determining the Amount of Bank Financing: Small and Medium Industries in Indonesia
}

\author{
Rachmad Hidayat \\ Department of Industrial Engineering \\ University of Trunojoyo Madura \\ Madura, Indonesia \\ rachmad.trunojoyo@gmail.com
}

\author{
Muhammad Azmi Alamsyah \\ Department of Industrial Engineering \\ University of Trunojoyo Madura \\ Madura, Indonesia \\ azmi.utm@gmail.com
}

\begin{abstract}
The present study addressed the simulation of conventional and Islamic bank financing systems. This simulation involved 20 small SMEs which were divided into 2 groups: salt farming SMEs (low-risk business) and shrimp farming SMEs (high-risk business). The three principles of experiment design applied in this study were randomness, repetition, and environmental control. The SME actors were required to borrow from the bank in order to run their business. By fulfilling the 3 principles of the experimental design the simulation can be run. The present study was conducted by having any of the SME actors to borrow additional capital from banks, which were the conventional banks with its interest rate system and the Islamic banks with its profit-sharing system. Results showed that the high-risk actors of SMEs tended to borrow more from Islamic banks than conventional banks. This was due to the probability of larger operating losses, leading the SME actors to minimize losses by borrowing from Islamic banks due to the sharing of gains and losses.
\end{abstract}

Keywords-Islamic banks; SME; financing system

\section{INTRODUCTION}

An experimental design is a method for taking economic decisions by means of observations made by controlling the environment. Environmental control is described as economic actors and rules or scenarios of interaction among those economic agents [1]. Environmental control is difficult since humans basically are said to be economic actors with diverse characters in making decisions and facing particular situations. Smith developed the Induce Value theory to control the characteristics of the economic actors. This theory provides an explanation that economic actors have the character of continually looking for rewards to greatest extent possible in the conduct of economic activity. This theory can be used by researchers to induce economic actors characteristics and render other characteristics no longer having an effect. When the economic environment (the basic characteristics of economic actors) can be controlled the experimental design can be carried out [2].
The experimental design of the present study involved the conventional and Islamic bank financing systems. The three principles of experimental design applied were randomization, repetition, and environmental control. The first principle of randomization was applied to both small and medium entrepreneurs as the experimental objects with equal opportunities. Each SME had their own inflation data and revenues for each period. The second principle of repetition was applied by repeating the experiment 5 times or for five periods. At each period, the treatments and controls were homogenous so that there was no difference among periods. The third principle of environmental control was applied by using the Induced Value Theory. The theory was applied by rewarding those SMEs with the greatest profit at the end of the period.

\section{METHODS}

An experimental design is a method of data collection and analysis that is effective in assessing causal relationships among variables. An experimental design provides researchers with an opportunity to change the value of a desired variable or a factor based on the study needs. However, there is in the experimental design another factor which has a constant value (ceteris paribus); thus, the effects of the variable or factor can be clearly determined [3]. This is also called the experimental method. The experiment of the study was carried out by giving treatments to the subjects to conduct and experience the experiment with the aim of explaining the phenomenon in question. The purposive sampling technique was used to collect data. This technique was used since the researcher believe that the respondents could help the study due to their knowledge in relation with the study scenario [4].

\section{DISCUSSION}

The present study used the Induced Value Theory. The theory, stating that every economic actor has the character of continually looking for rewards to greatest extent possible in making decisions in the conduct of economic activity, was used for environmental control can be found in Figure 1-2. In order to apply the theory the character of continually looking 
for rewards to the greatest extent possible needed to be induced. SME actors should set up strategies to gain profits to greatest extent possible. For an evaluation, every SME actor was given an observation sheet that contained the motivation with regard to making economic decisions. The observation

The initial hypothesis of the study was that there was difference in decision making by the SMEs, leading to risks with regard to determining the amount of loan to conventional and Islamic banks. The hypothesis would be subjected to analysis of variance (ANOVA); however, the average customer tendency to determine their loan amount should be known. Based on the financing system, the highrisk SMEs tended to borrow more from Islamic banks than from conventional banks. However, for SMEs with low risk tend to borrow more in conventional banks.

There was a large difference in profits between customers with low business risks and those with high business risks.

TABLE I. REVENUE OF LOW-RISK BUSINESS

\begin{tabular}{|c|c|c|c|c|c|}
\hline \multirow{2}{*}{ No } & \multicolumn{5}{|c|}{ Revenue of Low-risk Business } \\
\cline { 2 - 6 } & Period 1 & Period 2 & Period 3 & Period 4 & Period 5 \\
\hline 1 & $20 \%$ & $20 \%$ & $10 \%$ & $20 \%$ & $20 \%$ \\
\hline 2 & $10 \%$ & $20 \%$ & $10 \%$ & $30 \%$ & $10 \%$ \\
\hline 3 & $20 \%$ & $10 \%$ & $20 \%$ & $0 \%$ & $20 \%$ \\
\hline 4 & $10 \%$ & $20 \%$ & $20 \%$ & $30 \%$ & $10 \%$ \\
\hline 5 & $30 \%$ & $20 \%$ & $20 \%$ & $20 \%$ & $20 \%$ \\
\hline 6 & $20 \%$ & $-10 \%$ & $20 \%$ & $20 \%$ & $10 \%$ \\
\hline 7 & $0 \%$ & $30 \%$ & $-10 \%$ & $10 \%$ & $0 \%$ \\
\hline 8 & $10 \%$ & $20 \%$ & $20 \%$ & $20 \%$ & $20 \%$ \\
\hline 9 & $20 \%$ & $10 \%$ & $10 \%$ & $10 \%$ & $20 \%$ \\
\hline 10 & $20 \%$ & $20 \%$ & $20 \%$ & $20 \%$ & $-20 \%$ \\
\hline
\end{tabular}

\section{A. ANOVA of Bank Financing Systems}

Analysis of variance (ANOVA) is a method for breaking down data variance into components of multiple sources. In the present study, ANOVA was conducted by using the Minitab software. The loan amount was the amount of additional capital provided by banks to SMEs. The loan amount was an amount subjectively desired by customers without any provision; however, the maximum amount that could be borrowed by each SME amounted to 10000. Data of customers' loan amount, consisting of 10 low-risk SMEs and 10 high-risk SMEs in conventional banks and Islamic banks, were averaged to determine the average customer profit of each period. Data of the five periods serving as repetition in this study were averaged again for variance. Results of ANOVA of customers' loan amount using Minitab software can be found in Table 1.

Business risk and type of financing system did not affect the loan amounts of customers or SMEs, as shown by the smaller value of $F_{\text {count }}$ than that of $F_{\text {table }}(161.447)$ or a p-value greater than $\alpha(0.05)$. There was no difference between the small and large business groups as well as between the bank financing systems of conventional and Islamic banks in making decisions of the customers' desired loan amount. sheet showed that $100 \%$ of SME actors made decisions with the motivation to gain profits to greatest extent possible. In the present study, therefore, the Induced Value Theory has been met as an environmental control [5].

The difference was approximately $1 \%$. Based on the financing system (the interest system of conventional banks vs. the profit-sharing system of Islamic banks), there was no large difference despite the higher profits gained by customers using conventional banks. The difference was less than $0.1 \%$. This large difference in customers' profits based on the business risk was reasonable due to the inflation rate and revenues experienced by every low- and high-risk SME actor. Since the inflation rate faced by the high-risk businesses was more fluctuating than that of the low-risk businesses, the profits were also more fluctuating and the revenues tended to be more volatile and had a greater chance of loss can be found in Table 1-2.

TABLE II. REVENUE OF High-RISK BUSINESS

\begin{tabular}{|c|c|c|c|c|c|}
\hline \multirow{2}{*}{ No } & \multicolumn{5}{|c|}{ Revenue of Low-risk Business } \\
\cline { 2 - 6 } & Period 1 & Period 2 & Period 3 & Period 4 & Period 5 \\
\hline 1 & $-3 \%$ & $19 \%$ & $-25 \%$ & $8 \%$ & $19 \%$ \\
\hline 2 & $8 \%$ & $8 \%$ & $19 \%$ & $19 \%$ & $-3 \%$ \\
\hline 3 & $8 \%$ & $8 \%$ & $-14 \%$ & $19 \%$ & $30 \%$ \\
\hline 4 & $8 \%$ & $19 \%$ & $8 \%$ & $8 \%$ & $19 \%$ \\
\hline 5 & $19 \%$ & $-25 \%$ & $-3 \%$ & $30 \%$ & $8 \%$ \\
\hline 6 & $19 \%$ & $19 \%$ & $8 \%$ & $8 \%$ & $19 \%$ \\
\hline 7 & $30 \%$ & $8 \%$ & $19 \%$ & $19 \%$ & $8 \%$ \\
\hline 8 & $30 \%$ & $19 \%$ & $19 \%$ & $-3 \%$ & $8 \%$ \\
\hline 9 & $8 \%$ & $8 \%$ & $8 \%$ & $-14 \%$ & $8 \%$ \\
\hline 10 & $19 \%$ & $30 \%$ & $19 \%$ & $-3 \%$ & $-3 \%$ \\
\hline
\end{tabular}

TABLE III. ANOVA OF CUSTOMERS' LOAN AMOUNTS

\begin{tabular}{|c|c|c|c|c|c|}
\hline $\begin{array}{c}\text { Sources of } \\
\text { Variance }\end{array}$ & DF & SS & MS & $\mathbf{F}$ & $\mathbf{P}$ \\
\hline $\begin{array}{l}\text { Financing } \\
\text { System }\end{array}$ & 1 & 3481 & 3481 & 0.03 & 0.884 \\
\hline Business Risk & 1 & 2325625 & 2325625 & 22.85 & 0.131 \\
\hline Error & 1 & 101761 & 101761 & & \\
\hline Total & 3 & 2430867 & & & \\
\hline
\end{tabular}

Each of these SMEs had different courage in taking risks. There were SMEs that were willing to take risks with consideration of a sufficiently higher chance of gaining larger revenues. This type of SMEs tended to borrow larger capital than that of non-risk-taking SMEs. The former SMEs had a principle of not being afraid of gaining a small income since the chance of gaining a higher revenue was much greater. However, there were also SMEs not daring to take risks and decided to play safe in order to prevent from suffering huge losses. This type of SMEs had a principle of disregarding small profits, provided that the losses were small in the first period of their business since he bank loan was also small. 
The present study did not take into account the character of economic actors in the face of risks. In one group of business risks, there were risk-taking SMEs and non-risk-taking SMEs. Thus, the study did not found significant differences between the groups. In addition to the character in facing risks, profits also constituted the factor affecting SMEs in determining the desired loan amount. SMEs were well aware of the fact that the profitsharing system applied by Islamic banks would be more profitable when their business had a risk of substantial losses. Similarly, the interest-rate based capital returns as applied by conventional banks would be more profitable when the chance of higher revenues were greater and the business risks were small. This was why there was no difference between the high risk SMEs and the low-risk SMEs due to the fact that SMEs tended to gain profits to the greatest extent possible. The loan amount proposed by customers can be written in the following mathematical model:

\section{Loan amount $=8986.5+59$ Treatments -1525 Groups}

The above mathematical model showed that the loan amount would rise by 59 rupiah when using the financing system 1 (interest rate system) and would rise by 118 rupiah when using the financing system 2 (profit-sharing system). Furthermore, the customer's loan amount would drop by 1525 rupiah when the business risk is low and would drop by 3050 rupiah when using a high-risk venture.

\section{B. Analysis of SME Actors' Profits}

The customer's profit level constitutes the net present value (NPV). Recapitulation of customers' percentage profit. Data of customers' profit levels, consisting of 10 low-risk SMEs and 10 high-risk SMEs in conventional banks and Islamic banks, were averaged to determine the average customer loan amount of each period. Data of the five periods serving as repetition were averaged again for variance. Results of ANOVA of SMEs' profit levels using Minitab software can be found in Table 2.

TABLE IV. ANOVA OF SMES' PROFIT LEVELS

\begin{tabular}{|l|c|c|c|c|c|}
\hline $\begin{array}{c}\text { Sources of } \\
\text { Variance }\end{array}$ & DF & SS & MS & F & P \\
\cline { 1 - 5 } $\begin{array}{l}\text { Financing } \\
\text { System }\end{array}$ & 1 & 0.00202 & 0.00202 & 665.81 & 0.025 \\
\hline Business Risk & 1 & 1.00208 & 1.00208 & 330272.3 & 0.001 \\
\hline Error & 1 & 0 & 101761 & & \\
\cline { 1 - 4 } Total & 3 & 14.4707 & \multicolumn{3}{|l}{} \\
\cline { 1 - 3 }
\end{tabular}

Business risk and type of financing system affected the profit levels of SMEs, as shown by the larger value of $F_{\text {count }}$ than that of $F_{\text {table }}(161.447)$ or a p-value smaller than $\alpha(0.05)$. There was a difference between low-risk business and highrisk business groups as well as between the conventional and Islamic bank financing systems. It was due to the difference in the probability of gaining higher profits between each business risk group. In the low-risk SME group, the probability of gaining larger profits was much higher than that of the highrisk SME group. The probability of gaining larger profits greatly affected customers' profits. And so did the differences between the conventional and Islamic bank financing systems. The gain or loss experienced by SMEs depended on the financing system used. When businesses were losing money, Islamic banks became the solution to minimize the losses, in contrast to conventional banks whose capital loan repayment always used interest rates. Thus, when the business was losing money, SMEs did not bear the loss, but it was distributed to the Islamic bank in accordance with the agreement.

In contrast, when the business was profitable, the best option was to borrow capital from a conventional bank. Conventional banks did not require large returns according to SMEs' increase in revenues. This point was in contrast to the profit-sharing system of Islamic banks. Results of the experiment for customers' profits can be written into the following mathematical model:

Cust. profits $=2.2761-0.0449458$ Treatment -1.00104 Group

The above mathematical model showed that customer profits would decrease by $0.0449458 \%$ when using the financing system 1 (interest-rate system) and would decrease by $0.0898916 \%$ when using the financing system 2 (profitsharing system). Furthermore, the customer's loan amount would drop by $1.00104 \%$ when the business risks was low and would drop by $2.00288 \%$ when using a high-risk venture.

\section{CONCLUSION}

This economic experiment was carried out by having SMEs to borrow additional capital from banks, which were the conventional banks with its interest rate system and the Islamic banks with its profit-sharing system. the high-risk actors of SMEs tended to borrow more from Islamic banks than conventional banks. This was because of the probability of smaller losses and larger revenues greater; thus, it would be more profitable to borrow from conventional banks. By contrast, the high-risk SMEs tended to borrow more from Islamic banks than from conventional banks. This was because of the probability of larger operating losses, leading SMEs to minimize losses by borrowing from Islamic banks due to the sharing of gains and losses

\section{ACKNOWLEDGEMENT}

We would like to thank to University of Trunojoyo Madura for the support and Universitas Muhammadiyah Sidoarjo for publication opportunity.

\section{REFERENCES}

[1] Gächter, S., Orzen, H., Renner, E., \& Starmer, C. (2009). Are experimental economists prone to framing effects? A natural field experiment. Journal of Economic Behavior \& Organization, 70(3), 443446. 
[2] Offerman, T. (2013). Beliefs and decision rules in public good games: Theory and experiments. Springer Science \& Business Media.

[3] Friedman, D., \& Sunder, S. (2011). Risky curves: from unobservable utility to observable opportunity sets..
[4] Cooper, D. R., Schindler, P. S., \& Sun, J. (2006). Business research methods (Vol. 9). New York: McGraw-Hill Irwin.

[5] Diebold, F. X., Schuermann, T., \& Stroughair, J. D. (2000). Pitfalls and opportunities in the use of extreme value theory in risk management. The Journal of Risk Finance, 1(2), 30-35. 